\title{
Climbie Bernard B Dadi: a scriptural rhetoric métachronique of afropolitanism
}

\begin{abstract}
Climbie by the Ivorian writer Bernard B. Dadié Appears as a panafricanist ideal refoundation novel since "movement of the Worlds" in the year tale shows African solidarity gradually converging to a mentality of blackness. The woven friendship and enmity report evade racial thoughtfulness. Black people have two cultures: the first, black ancestors inherited and the second left by white colonizers. As Such, this work is an unsuccessful phenomenography of Panafricanism and Appears as preterm ultimately textualization of afropolitanism, this sense of identity of the nesting here and the elsewhere.
\end{abstract}

Keywords: panafricanist ideal, circulation of the worlds, african solidarity, blackness, afropolitanism
Volume 3 Issue 3 - 2018

\author{
Arsene Wheat Kain \\ Department of Modern Languages, University Alassane \\ Ouattara, Côte d'Ivoire
}

\begin{abstract}
Correspondence: Arsene Wheat Kain, Department of Modern Languages, University Alassane Ouattara, Côte d'Ivoire, Email blekain!@yahoo.fr
\end{abstract}

Received: September 29, 2018 | Published: May 17, 2018

\section{Introduction}

In Out of the big night-Test on the decolonized Africa, Achille Mbembé reveals that roaming, mobility and movement are major paradigms out of which the cultural history of the African continent does not understand. This culture of mobility, which can be seen through the constitutive migration of the diasporas and by commercial exchanges of all kinds and even by slavery and colonization, leads him to conceive a contemporary African modernity based on a cultural, historical and aesthetic sensibility it indicates under the name neological of afropolitanism, that is to say, The awareness of this intertwining of the here and elsewhere, the presence of elsewhere in the here and vice versa, this relativisation of roots and primary belongings and this way of embracing, knowingly the strange, foreign and distant, the ability to recognize his face in the face of overseas and enhance the traces of the distant in the near to domestiq uence the in-familiar. ${ }^{1}$

Such apprehension of the identity of Africans based on interpenetration of various racial cultures seems the principle of a novel of the African colonial era as Climbie. ${ }^{2}$ The work is part, of the multiple're roaming for the characters, especially the title character, a graspable cosmopolitan spirit here under the Afropolitan angle rather than following the colonialist practices or pan-Africanist. The basic question is to identify the discursive and ideological devices that can bring out the book of Bernard B Dadié traces of premature practice of afropolitanism once the characters seem to share the experience of racial cultures plural. To what extent and under what conditions the afropolitanism if he deploys, in other words, in Climbie? As part of a perspective both socio-pragmatic and postcolonial, this study analyzes one of the optical identity that the novel could be read Dadié. It thus reveals at first glance that " the circulation of worlds "Perceptible in this literary work should not be interpreted as an attempt to reconfigure the ideal panafricanist then reveal that the game of mobility that takes place there is rather the premonitory sign of a characteristic praxis of afropolitanism.

\section{The circulation of worlds in climbie: a failed attempt to reconfigure the pan-african ideal}

Achille Mbembe, ${ }^{1}$ the phenomenon of the circulation of worlds Presents two faces: Dispersion, which made Africa a starting point to other regions of the world, including the current result is the conversion of many people of African origin citizens in various countries of the world; and immersion involving populations from other continents, now rooted in Africa. These populations have lost all contact with their origins (European or Asian) and have become "cultural bastards". And even if they claimed a certain superiority in the name of race and marked their difference, even their contempt for everything that is "African" or "native", most of these "foreigners" expressed themselves in local languages, know and practice certain customs of the country, even if they still live in relatively closed and endogamic communities. In Climbie, this "circulation of worlds" At work through the roaming characters reveals some African solidarity converging towards a mentality of blackness, although the novel occurs, eventually as an unsuccessful phenomenography of Pan.

\section{The itineraries of the characters: African solidarity in the blackness'}

The traffic movement is the major characteristics of the novel by Bernard Dadié. This mobility is perceptible to the many displacements of the characters, especially those of the eponymous character. The narrated story evolves, in fact, from travel Climbie. These trips, which are closely linked to his schooling, are carried out in his home country of Côte d'Ivoire and in an extra national space, Senegal. From the start of the work, one discovers Climbie in camp with his uncle $\mathrm{N}$ 'Dabian. In this camp presented later, as the Boudéa it assists his uncle in various tasks and learns by his side his work as a man (8). On the recommendation of blessed aunt, his wife's uncle decides to place his protege in a school so that it "suffers the fate [imposed] upon him [his] uncle who hid him at the time of the school recruitment (15). Climbie and leaves the camp for Grand-Bassam, where a little more each day, he forgets country life of Boudéa. His only worries are now to get a good grade, a good place in school; this ardor at work earned him access to the Grand-Bassam regional school, which he subsequently left for the town of Bingerville when he was admitted to the EPS.

The movements of Climbie in Ivory Coast are made primarily in the area of Grand-Bassam and Bingerville, two cities in the Southeast. Its mobility remains restricted to a spatial framework

${ }^{1}$ Complex and ambivalent notion, the blackness could be translated as the identity and black consciousness in his report that some critics describe as hiteness or "dominant white consciousness." It is of a black cosmopolitanism. 
that is much more regional than national. The birth of the colonial school in Ivory Coast particularly on the coast and the site of GrandBassam, at the time, capital, certainly justifies the trajectory of the character Climbie underpinned by a frantic quest for knowledge. Having successfully passed the entrance examination for the Ecole Normale William Ponty, he is forced to abandon the national territory to migrate to Goree in Senegal (102). In the ship that leads to it, its neighbor Dossou, a student of Dahomey, who knows the course and used him on occasion guide. The two neighbors call each other "fofo, That is, brothers (107). Climbie then exits William Ponty to enter the workforce as an administrative clerk in Dakar (119). He discovers certain equality between Whites and Blacks and takes advantage of it to frequent the places of amusement common to Africans and Europeans (119). It exchanges with young directors expressly African colonies came under the leadership of the Popular Front for French used the new colonial policy (120). He goes in the labor setting, Tiaroye (131) and St. Louis (159), with as traveling companion to the first destination, Dassi, a young Togolese. He is nevertheless forced to stop his wanderings in Senegal to return to Cote d'Ivoire, where he has just been reassigned.

Multiple human contacts that are created from the many movements are symptomatic of this Climbie Achilles M'Bembé calls "circulation of worlds". They can discover, among blacks, some racial solidarity inscribed in the blackness. In Climbie racial solidarity appears in the African way of life. Already in his native Climbie achieves a certain communion with Africans from other countries. The proof is in GrandBassam, where he took his first steps at school, around Climbie carrier "symbol", ${ }^{2}$ Dahomean students mingled with their peers éburnéens sing in unison: "Talk Agni, I give you the symbol/Ah! ha! I give you the symbol. You speak Bauli, I give you the symbol, Ah! ha! I give you the symbol (19). This definable racial solidarity to as blackness is also seen through the presentation of old Senegalese established in Ivory Coast since a young age and have never returned home: Under the almond trees in Cayenne, bowlers and cards near them in large old Senegalese boubou in their couch, the big stick between his legs, spoke of the time, while young, they put their feet in Ivory Coast. Today, they have almost no teeth, have never returned home (57). The complicity that seems to prevail among Africans does not, however, disguise the fact that they do not always maintain friendly relations with each other. The mentality of blackness that one might find in their mutual aid and friendship relations leads, therefore, not to Pan-Africanist spirit to which one would logically expect, Climbie Moreover, as such, an unsuccessful phenomenography of PanAfricanism.

\section{Climbie, an unsuccessful phenomeno-graphy of pan}

Appearing towards the end of the nineteenth century in the Caribbean to describe a movement of revolt of Africans confronted with slavery in America and the colonial domination of the Europeans in Africa, panafricanism appears in its first version as a movement of emancipation Africans and means for Blyden and Garvey, ${ }^{3}$ a return of blacks to the land of their ancestors. First perceived as a political

${ }^{2}$ In colonial school, the e symbol was an object cumbersome and often smelly that the teacher handed punishment sign a student caught speaking the regional language instead of the language of the colonizer.

${ }^{3}$ Edward Wilmot Blyden (1832-1912) is considered one of the father s of pan when Marcus Mosiah Garvey (1887-1940) is one of the main figures of the movements sent to the masses. movement that promotes and encourages the practice of solidarity among Africans wherever they are in the world, Pan-Africanism appears as a social, cultural and political vision of their emancipation in order to to unify those of the continent and the diaspora. Finally, pan-Africanism is a nationalist practice on a large scale. For Mbonda ${ }^{3}$ To be a nationalist is to show a certain attachment to his nation, both in the form of preferential loyalty and in the form of devotion to its becoming. Pan-Africanism corresponds roughly to the same preoccupation: Working for the liberation of the whole of the yoke of foreign domination Africa and also for its unity and its social, economic and political. It goes well beyond the simple black unity consciousness that characterizes the blackness to appear ultimately as a holistic political unification of blacks and development of the whole of Africa. This company is to take over as a single people with specific problems and specific solutions to them, discovered, for example, in the romance of Dadi, during the general strike of workers black. The General Secretary of the Union of Trade Unions addresses the activists as Africans first: "African comrades, we have been fighting this struggle for a long time. (153)

It is not a coincidence that Climbie finds the Togolese Dassi which he met during the trip to Tiaroye and yet now works as a policeman in the Ivorian civil service (203). In the same vein, Bernard Dadié, linking Africans and drums, advance remarks imbued with a real Pan-African feeling: I have come to understand that everything in the European in this country is a reflex of self-defense against the climate first, then against men, maneuvers, the intellectual, the child who goes to school and more so against the tam-tams. It will certainly take a number of years before the child becomes a serious competitor, if given the opportunity, but the tom-tom, Seeking our hearts, minds and souls to realize total assimilation, he said to himself: "How can I dominate this continent, these men, when the tam-tam, every night, holds ancestral language, connects them in the past (...) It is certain that young people do not understand all your language, but instinctively, they respond : "Present "You are part of the community (...). Tam-tams of funerals and tam-tams on holidays! You can play July $14^{4}$ and 11 November, ${ }^{5}$ you keep saying glazed French words choruses, you remain specifically African (207).

This pan-Africanist consciousness certainly justifies the fact that the Ivorian Climbie and Dahomey Dossou call each other "fofo, That is, brothers (107). In reality, Climbie is not a novel defense and illustration of black culture; nor is it a work of promotion of black racial solidarity. Some Blacks are, in fact, closer to Europeans than to their brothers of race. One of the best friends Climbie Mr. Buckler, a European photographer with whom he had regularly exchanges and whose letter to Climbie closes the novel (208). The conflict between blacks and whites certainly result racially antagonistic reports due to the colonial situation, but they are mostly the result of natural frictions that arise from the coexistence of men. The reflection of Mr. Buckler answering Climbie accusing whites of racism is, for this purpose, informative: We have moments of crisis. This happens to any man. It happens to us in Europe, as it happens to you here. These are moments of cockroach because, because... It is the bad weather of man [...]. But it passes. Thus, I have fifteen years of colony, which I did not tolerate in France; I do not tolerate it here either. The drama is to say: I am not White, I am not African; but after all, are we not men in the same way? (160-161)

${ }^{4}$ On July 14 is the national holiday of the French Republic.

${ }^{5}$ On November 11, recalls the signing in 1918 of the armistice that ended the fighting of World War II, the Allied victory and total defeat of Germany. 
On The Marie Paul, the boat which brings the Ivory Coast, Climbie also the memorable experience of sympathy vis-à-vis a white Black, where the Black discredit. It is treated with great respect by Mr. Jeline a European sailor (177), while the storekeeper and the black cook despise royally: At lunch, Climbie in second class passenger who agreed to travel in steerage, the storekeeper serves neither read nor wine and cook three dishes, not give him a saying: "You do not work, you do not have the right to eat". (178) worse, when a white sailor tries to reason with him, it launches violent invectives against Climbie: "Let him go to the cabin and make him peace. For the moment, it is in entrepot and more a useless mouth (178). The enmity between black characters appears in broad daylight through the situation of privileged Dahomeans in Cote d'Ivoire who boast about the progress of their country, compared to Côte d'Ivoire "wild": "The Dahomeans occupied the best places in the offices, filled other cousins' jobs, at the same time that they were dismissing natives". (54); hence the tensions that arise between the two communities. Better yet, in the novel of Dadi, Europeans openly side with the blacks. So is the European woman who, in Conakry, Guinea, defends her husband, a native sergeant arrested by jealousy by other Europeans: gentlemen! It may seem strange to you that we married Negroes. For us, this is not unusual. During this war, in our region, they helped us to live at a time when we were always wondering what tomorrow would be. We ourselves had neither boys nor provisions at our discretion. You can do racism. In France, we know this word because it is in the dictionary. It is not in our actions, in our facts, in our thoughts. He does not exist. I you mande thus free my husband (181).

The communion between Whites and Blacks is equally manifested on various, even banal occasions: Europeans support local football teams (191); Blacks and Whites shoot together on the lines thrown by sailors to catch fish (178-179) ; Blacks are enlisted to wage war alongside their European friends (125). Climbie is not a novel of praise or promotion of pan once the relationships between whites and blacks remain, in many ways, full of cordiality. Negroes seem, incidentally, to participate in two cultures: One inherited from ancestors (the culture of here) and the other left by the white colonizers (the culture of the way). This reality participates in the reflection Climbie Dassi made during the bus trip to Tiaroye: And if I said in my turn that we must read much, perhaps more than any other people in the world, because we are precisely at the crossroads of two civilizations ? (...). We, torn between the European who has his traditions and the old ones based on the custom that makes their strength, what do we become ? (133-134) The creolization because the African people so described develop a transnational culture inherent to roaming practices, migration, movements undoubtedly emerged from the afropolitanism concept initiated in 2005 by Achille M'Bembé. Climbie novel of African colonial era that presents countless eponymous character's movements appears, therefore, as an early scriptural practice of afropolitanism.

The game of mobility in Climbie: premonitory index of a characteristic praxis of afropolitanism

Mobility is today an important dimension of social life, since it is what the structure. It is a main historical characteristic of African peoples and involves trajectories which meet the negro people everywhere, so Africans everywhere. Achille Mbembé illustrates this situation of citizens of the world when he says That there is a part of African history elsewhere, outside Africa He is also a history of the world in which Negroes are, of necessity, actors and stakeholders. ${ }^{1}$ Consequently, Their way of being in the world, their way of "being world "To inhabit the world, [...] has always done under the sign if the cultural mix, at least the overlapping worlds, in a slow and sometimes incoherent dance they have hardly had time to choose freely, but which they have succeeded, as best they can, in domesticating and placing at their service. ${ }^{1}$ Thereby taking to their account this major paradigm of what afropolitanism mobility Climbie of Dadié finally is it not a literalization preterm involuntary Achilles concept M'Bembé?

\section{Mobility, a major paradigm of afropolitanism}

In a general sense, mobility refers to a movement, transfer, change one thing (hardware and/or non-material), of a person and information from one point to another. This term, however, is far from designating today only the real displacement in space by describing only the relations that man maintains with this space; hence the reconsideration of the definitional and methodological approaches of the notion by several theorists. Gilles Deleuze ${ }^{4}$ conceives mobility according to an approach based on the art of cinema which introduces life into the image. It is a principle at once mental, psychic and physical. The Deleuzian man is thus a truly mobile man, a cosmic man who perceives the universe in motion and constant creation and whose identity then becomes universal, cosmopolitan. Arjun Appadurai ${ }^{5}$ determines, in generic terms, like all "global flows" In which one can store the displacement of populations and cultural assets presented in landscapes (male migration, development of mass media that allow for information worldwide, traffic of all kinds of imaginary related ideas individual and collective). This mobility means that individuals and social groups are no longer linked to intrinsic localities (for example, particular nation-states), but rather create their own premises and thus produce new deterritorialized identity spaces.

Zygmunt Bauman, ${ }^{6}$ for its part, calls liquid modernity of the incessant flow of the current mobility life. In the "liquid company "He says, the only reference which is the individual integrated by his act of consumption has a definite place only by the individual choices he makes. Its identity therefore fluctuates with the requirements of flexibility, mobility: it is therefore not fixed ad vitam aeternam. The term "mobility "And contains an idea of moving. It involves the encounter, the negotiation, the production of trajectories that can be followed as people and goods move in a physical or imaginary space, most of the time, transnational. It occupies a prominent place in the concept of afropolitanism the Cameroonian historian Achille M'Bembé. The traffic movement, the movement is, indeed, major paradigms that lead to afropolitaine consciousness, this sense of a nested here in addition, result of physical movement of people, but also those they perform in through their imagination. Mobility (circulation, movement, movement) therefore remains characteristic of the modern African period and even of that of the past. In this regard, Catherine Mazauric ${ }^{7}$ épiloguant on the movements of the character Climbie says that these "register on the backdrop of mobility in space which is previously "a fundamental fact of Sahelian Africa before colonization and debuted". ${ }^{8}$ Taking elsewhere on his own the words of Jean-Loup Amselle9 it qualifies West Africa where Climbie moves are of "international space" Climbie remains in this logic of mobility: the multiple displacements of the main character inside the native country, but also outside this country remain emblematic of 
the " circulation of worlds And undoubtedly reveal the experience of various worlds made by the characters of the novel. The characters blend into the various worlds they traverse by sharing the cultures that are conveyed there, while remaining attached to theirs. The claim of Jean Dérive ${ }^{10}$ states that "In principle, the identity of the [francophone] space is based upon the centripetal attraction force of core in historical reference, namely France as a metropolitan-stallion "Seems thus obsolete. The afropolitaine consciousness is not in fact a simple and banal attitude of assimilation, acculturation; it consists rather, through the experience of the circulation, to integrate the world of the others to his. By marrying the eventful journey of the main character and mingling harmoniously peoples of diverse origins, Climbie certainly follows a route Afropolitan identity, although this term is métachronique to colonial times when the novel was published.

\section{Climbie or prodromal textualization of afropolitanism}

Of course the character Climbie, from his childhood to his return home, an identity emerges trajectory: That of a national sentiment, mutating, as and measuring the movements of the characters, a seemingly Pan Thought, finally truly present as an afropolitaine consciousness. Climbie effectively fulfill the essential characteristics of the afropolitanism anchored in mobility. The different moves that the characters take, especially those that take place in an extranational setting, make it possible to forge such a mentality in them. The characters are not only national of their country; they are neither African nor European, since they share two cultures and feel of both cultures. It is this ambivalence of colonial cultural identity that develops Homi Bhabha's theory of hybridity. For him, hybridity" opens, in the metaphorical sense, a space in which a new colonial object is constructed "Which is neither the colonized nor the colonizer, but something intermediate which he describes as" third space "That is to say a place where purity, polarities and essentialisms are abolished. ${ }^{11}$

The extranational moving Climbie that drives those of the other characters imply such a mix. It certainly takes place exclusively between the Ivory Coast and Senegal, two seemingly identical areas of Africa, but the reality, the places represented is ethnoscapes ${ }^{6}$ cosmopolitics. Dakar, for example, presents itself as a Creole city where Asians, Europeans and Africans of various nationalities meet. One of the most popular places of entertainment shared by Europeans and Africans is the property of a Chinese (122). This melting pot that goes beyond the purely mental framework leads to a mix of cultures and a sharing of diverse cultural experiences. Thanks to these encounters, the characters of the novel are imbued with the cultural realities of other worlds. Their identity remains affected as soon as these experiences enrich them and they adopt certain practices that relate to them in the end. The Senegalese, for example, enjoy the status of a French citizen and enjoy it fully. In Côte d'Ivoire, for admission to the cinema, they are given preferential treatment compared to other blacks. They are considered in the same way as whites: "The Europeans, the Syrians and the Senegalese entered by another door, without any jostling. They stood there watching the howling crowd fighting to see the "white magician" (39). They take pleasure in this situation which they do not denounce beyond measure, feeling perfectly French somewhere. This awareness of belonging to Senegal ${ }^{6}$ The landscape of individuals (tourists, immigrants, refugees, exiles, migrant workers and other individuals and groups traveling) that contribute to the making of the changing world in which we live". ${ }^{5}$ as well as to France makes it possible to understand their eagerness to be enlisted to fight for France invaded during the Great War: "The recruiting offices for months were besieged by enthusiastic people in a hurry to fight."(125)

The characters and participate Climbie of consciousness afropolitaine because, at the turn of their movements, they develop a transnational culture. This international culture, even transcontinental, is a true mixture of interdependent diverse cultures in which the characters are now recognizable and from which their lives are now ordered. The distinction between them and the others is blurred. The question that Climbie formula in exchange he has with Dassi his Togolese friend, is indicative of this situation "We, torn between the European who has his traditions and the old ones based on the custom that makes their strength, what do we become ? (134). The answer is certainly in the letter addressed to Mr. Buckler Climbie in the end romance: Today, we must and we want, in this penetration of races and peoples, give a preponderant place to knowledge, understanding and love. I say that we must go forward, boldly outline the roads that will follow the new caravans, the caravans of fraternity in a pacified world. (208)

This complementation of the races and peoples of which Mr. Targe speaks so well involves, unbeknownst to them certainly, the Westerners to the African culture that seems to haunt them: Climbie understood that a new class of Europeans rode the class of settlers, half-European Half African, with a special language that will go by affirming. These men in Africa will always think of their village. And when they return to their country, they will be in a hurry to return to Africa, because at home they have attitudes that often hurt the entourage. They gather in beautiful hotels, in their neighborhoods, multiply reinforced concrete structures to maintain, Africa is gaining on them, the claw, the brand forever. They have the blues in Africa. They nostalgia in Europe, They are not men of a continent ... but a kind of hyphen. (179) Whites and that blacks in whom "the same phenomenon is observed in young advanced Africans clash in their own environment" (180), thus remain between two cultures: that of the here and that of elsewhere.

The first night of Climbie, back in his homeland, remains, for example, troubled (190) : " He would walk-get up to speed of beings and things because he still remembers this sentence Nalba "On your return will not be like others who do not want to recognize us"" (191). It sits uncomfortably in his country, despite huge efforts to adapt or rehabilitation. The countless questions that flock to his head, on his arrival at the port of Abidjan, clearly demonstrate that state of being: "Why is it down why has he left Dakar where he had dug a bed? took habits? He was alienated from his country... Who knows in this country yet? "(188-189). Meet a cousin who acknowledges (190) and its commitment as a leader in the qualified strike "strike of agricultural products" in Ivory Coast which earned him being imprisoned (193-199) yet ultimately indicate his attachment to this country. Such cultural reconfiguration allows postulating that Climbie Bernard B. Dadi is a true scriptural rhetoric afropolitaine although this term remains prochronique for African colonial period in which this work is written.

This double identity postulation is summed up in the thought of Achille Mbembé12 confirms that " identity is rooted in the multiplicity and dispersal; that the reference to self is possible only in-between, in the gap between the brand and stands out in the co -constitution". So he concludes that, Colonization no longer appears as a mechanical and 
unilateral domination that forces the subject to silence and inaction. Instead, the colonized is a living individual, talking, conscious acting, whose identity is the result of a triple break-motion, scrub and selfrewriting. ${ }^{12}$ The self-rewriting, new social attitude to learn and feel both of here and elsewhere and the rhetoric that accompanies justify worldview that, this is not because a community welcomes foreign consents to their differences, even to their opacity, it distorts or risk perishing. It increases the contrary and thus complete. It gives luster to what it is, what it has, as it becomes and it offers this shine that to afford receives. ${ }^{13}$

\section{Conclusion}

The "movement of worlds" informs material Climbie Ivorian writer Bernard B Dadié. This presents work indeed, the eponymous character in its movements as well as place of origin, the Ivory Coast, in the extranational symbolized by Senegal space. Through the experience of several worlds made by the characters, the novel seems to remount the pan-African ideal that course since the nineteenth century. The residence Climbie in Senegal who lets discover some African solidarity molded into the blackness, the global awareness of the quest for wellness Black logically assume that aspiration pan-Africanist. The relationship between them black characters are however not always cordial fingerprints, tensions existing between certain communities and grave disregard facts to blacks being made other blacks. As such, Climbie cannot be considered as an activist for a cause novel pan-Africanist. The game of mobility that characterizes and makes the characters, mainly the main character, find themselves at the crossroads of diverse racial cultures and experience a cultural awareness of the here and the elsewhere attests that Climbie is scriptural rhetoric métachronique of afropolitanism.

\section{Acknowledgements}

None.

\section{Conflict of interest}

Author declares that there is no conflict of interest.

\section{References}

1. Mbembe A. Out of the Dark night. Essay on the decolonized Africa. Paris: La Découverte coll, Free books; 2010.

2. Dadié B. Climbie. Paris: Seghers, 1956.

3. Mbonda EM. Intellectuals African, patriotism and Pan-Africanism: to about the brain drain. In: Mangu MA, editor. Nationalisme and reconstruction panafricanism African. Dakar: Codesria; 2006. p. 11-22.

4. Deleuze G. The movement-image, Cinema I. Paris: Minuit; 1983.

5. Appaduraï A. After colonialism: The cultural consequences of globalization. Paris: Payot; 2001.

6. Zygmunt B. Liquid Life. Paris: Librairie Arthème Fayard; 2005.

7. Canute C. Migration taking the words Getting stories and images of migration. Paris: Blue Rider; 2014.

8. Borgomano M. The trip to the African and its transformations according Amkoullel, the child Fulani. In: Fonkoua R, editor. The Travel Speech. Africa-Antilles, Paris: Karthala; 1999. p. 207-216.

9. Amselle JL. Ethnic and spaces : for a topological anthropology. In: Amselle JL, Bokolo ME, editors. The heart of ethnicity. Ethnicity, tribalism and state in Africa. Paris: La Découverte/Poche, 1999. p. 24-26.

10. Drift J. Identity strategies of the French novel. Annals of the University of Savoy. University of Savoie; 1998. p. 135-154.

11. Homi KB. The places of culture. Paris: Payot; 2007.

12. Mbembe A. What is postcolonial thinking? Interview. Spirit For understand postcolonial thought. 2006. p. 117-133.

13. Slippery E. When the walls fall - National identity outside-the-law? Paris: Galaade-Institute of the all-world; 1997. 